\title{
The molecular epidemiology of Staphylococcus aureus of bovine mastitis origin
}

\author{
Tawheed Ahmad Shafi ${ }^{1 *}$, Baljinder K. Bansal' ${ }^{1}$, Shukriti Sharma ${ }^{1}$, \\ Dhiraj K. Gupta ${ }^{1}$, and Randhir Singh ${ }^{2}$ \\ ${ }^{1}$ Department of Veterinary Medicine, Guru Angad Dev Veterinary and Animal Sciences University, Ludhiana, \\ Punjab, India \\ ${ }^{2}$ School of Public Health and Zoonoses, Guru Angad Dev Veterinary and Animal Sciences University, Ludhiana, \\ Punjab, India
}

SHAFI, T. A., B. K. BANSAL, S. SHARMA, D. K. GUPTA, R. SINGH: The molecular epidemiology of Staphylococcus aureus of bovine mastitis origin. Vet. arhiv 91, 1-10, 2021.

\section{ABSTRACT}

The present study was aimed to understand the molecular epidemiology of Staphylococcus aureus (54 isolates), isolated from 422 milk samples obtained from 108 subclinical mastitis affected cows (CMT positive $\geq 1+$ in at least one quarter). The molecular epidemiology of Staphylococcus aureus was studied using coagulase (coa) gene polymorphism, 16S-23S ribosomal spascer (RS-PCR) polymorphism and Staphylococcal protein A (Spa) typing. Staphylococcus aureus produced 7 coagulase genotypes and 8 RS genotypes respectively. Coagulase genotype GTIII (730 bp) was the most prevalent (35 strains) followed by GTV (900 bp, 7 strains) and GTIV (800 bp, 4 strains), whereas RS genotypes GTA accounted for the highest number of strains (31 strains), followed by GTB (11strains), GTH (4 strains) and GTE (3 strains). Coagulase genotype CTIII (730 bp) showed the highest diversity, as isolates within it produced 5 RS genotypes, the majority of them belonging to the RS genotype GTA (29 out of 31 strains). Forty out of 54 Staphylococcus aureus samples isolated in this study were correctly typed by spa typing, and were assigned to 21 known spa types, and one new novel spa type t18462. The study revealed high diversity within Staphylococcus aureus strains, consisting of 7 coagulase genotypes, 8 RS genotypes and 22 spa types.

Key words: coa gene polymorphism; ribosomal spacer polymorphism; Staphylococcus aureus; Spa typing

\section{Introduction}

Mastitis, the inflammation of mammary glands, has infectious or non-infectious aetiology. Infectious causes are mainly of bacterial origin, and are broadly divided into minor and major pathogens (EBERHART et al., 1987). The species within the genus Staphylococcus are classified into coagulase-negative staphylococci (CoNS) and coagulase-positive staphylococci (CoPS), based on their ability to produce coagulase enzyme. Staphylococcus aureus, one of the most common coagulase positive contagious pathogens, causes both clinical and subclinical bovine mastitis worldwide (KARIMURIBO et al., 2005; MOMTAZ et al., 2011; HAFTU et al., 2012; GUPTA et al., 2015), and its presence in milk is a public health threat (D’AMICO and DONNELLY, 2011).

\footnotetext{
*Corresponding author:

Assis. Prof. Tawheed Ahmad Shafi, Department of Veterinary Epidemiology and Preventive Medicine, College of Veterinary and Animal Sciences, Maharashtra Animal and Fishery Sciences University, Parbhani- 431402, Maharashtra, India, Phone: +91968 2329 989; E-mail: tawheed78@gmail.com
} 
Different Staphylococcus aureus strains have been observed in bovine mastitis, varying in virulence and epidemiology, and various conventional methods, such as phage typing, biotyping and antimicrobial susceptibility testing, have been used to study the strain variation (LANGE et al., 1999; SU et al., 1999). Due to the low discriminatory power of these conventional tests, newer molecular methods have been developed to improve the typing of staphylococcal strains that exploit the variations in the arrangement of chromosomal alleles and in the content of accessory genetic elements. Different genotyping methods such as: analysis of chromosomal DNA after enzymatic restriction (BUSCH and NITSCHKO, 1999), random amplified polymorphic DNA, coagulase gene typing and polymorphism (GOH et al., 1992; ISHINO et al., 2007), spa (Staphylococcus aureus Protein A) typing (SHOPSIN et al., 1999), multilocus sequence typing (MLST) (ENRIGHT et al., 2000) and pulsed-field gel electrophoresis (PFGE) (ZADOKS et al., 2000, MELLES et al., 2007), have been used in the genetic typing of Staphylococcus spp.

Coagulase enzymes produced by Staphylococcus aureus strains showed polymorphism due to heterogeneity at the 3 ' coding region of the coagulase gene that consisted of $81 \mathrm{bp}$ tandem repeats, differing in number, and also in the location of $A l u \mathrm{I}$ and HaeIII restriction enzyme sites (HIMABINDU et al., 2009). Moreover, bacteria possess rRNA genetic loci containing genes for all three rRNA, i.e., 16S, $23 \mathrm{~S}$, and $5 \mathrm{~S}$, which are separated from one another by spacer regions, varying in length and sequence, both at genus and species level. Also, the good diversity due to variations in the number and type of tRNA sequences found within the spacers regions, was used to discriminate between different species/ strains of prokaryotes (BARRY et al., 1991). Spa typing is a PCR-based single-locus sequence typing technique, based on sequencing of the polymorphic region X of the Staphylococcus aureus Protein A (spa) gene (FRENAY et al., 1996). The spa locus consists of 24-bp nucleotide repeats, showing diversity due to deletions and duplications, and to a lesser extent by point mutations (SHOPSIN et al., 1999). The discriminative power of spa typing lies between PFGE and MLST (MALACHOWA and
DELEO 2010), and in contrast to MLST and PFGE, can be used to investigate molecular evolution and disease outbreaks caused by methicillin resistant Staphylococcus aureus (KOREEN et al., 2004). The main advantage of spa typing over MLST is sequencing of only a single locus, as compared to seven loci in MLST.

In the present study, we combined PCR based techniques, i.e. coa gene polymorphism, RS polymorphism and spa typing (DNA sequence based technique), to understand the molecular epidemiology of Staphylococcus aureus of bovine mastitis origin, from five agro climatic regions of Punjab, India.

\section{Materials and methods}

Milk sample collection. In total, 250 randomly selected dairy cows were included, 50 from each region of Punjab namely: the Central plain zone, the Sub-mountain undulating zone, the Undulating plain zone, the Western plain zone and the Western zone. The representative farms / animal herds in each region were visited during the regular evening milking hours, and animals were screened for subclinical mastitis using the California mastitis test (CMT). 422 milk samples from 108 mastitis positive dairy cows (CMT positive $\geq 1+$ in at least one quarter) were collected for bacteriological analysis. $10 \mathrm{~mL}$ of fore-quarter milk samples were collected aseptically in sterile $15 \mathrm{~mL}$ glass test tubes and carried to the laboratory in an icebox for bacterial analysis, as per the guidelines of the National Mastitis Council (HOGAN et al. 1999).

Microbial evaluation for identification of Staphylococcus aureus. Staphylococcus aureus was presumptively identified on the basis of colony characteristics on blood agar, Gram staining, clumping factor, growth characteristics on mannitol salt agar, DNase agar, Baird parker agar, tube coagulase test and by biochemical identification using a HiStaph identification kit (HiMedia Laboratories Pvt. Ltd., Mumbai, India). Staphylococcus aureus (ATCC 33591) and $S$. epidermidis (MTCC 3382) were used as standard controls. Individual Staphylococcus aureus isolates were stored at $-20{ }^{\circ} \mathrm{C}$ in trypticase soy broth containing $30 \%$ glycerol for future use. 
DNA extraction. $1 \mathrm{~mL}$ of overnight inoculum of an individual Staphylococcus aureus colony in brain heart infusion broth (BHI, HiMedia) was pelleted at $7500 \mathrm{rpm}$ for $5 \mathrm{~min}$ in refrigerated centrifuge (Heraeus Biofuge Primo R, Thermo Scientific). 180 $\mu \mathrm{L}$ lysis solution (lysozyme enzyme $20 \mathrm{mg} \mathrm{mL}^{-1}$; Tris $\mathrm{HCl} 20 \mathrm{mM}, \mathrm{pH}$ 8; Triton X 1.2\%; Tween 20 $0.5 \%$ and EDTA $2 \mathrm{mM}$ ) was added to the pellet and incubated at $37^{\circ} \mathrm{C}$ for $30 \mathrm{~min}$. Bacterial DNA was extracted using a QIAamp DNA mini kit (Qiagen) following the manufacturer's guidelines, and the eluted DNA was stored at $-20^{\circ} \mathrm{C}$ until further use.

PCR confirmation of Staphylococcus aureus. Duplex PCR amplification was carried out for the detection of genus specific $16 S \mathrm{rDNA}$ (STROMMENGER et al., 2003), and nuc (Staphylococcus aureus species specific) genes (BRAKSTAD et al., 1992). The amplification was carried out in a total reaction volume of 25 $\mu \mathrm{L}$ containing $12.5 \mu \mathrm{L}$ qiagen PCR Master Mix (Qiagen), $10 \mathrm{pmol} / \mu \mathrm{L}$ of each primer set containing forward and reverse primers (Table 1), $0.01 \mu \mathrm{g}$ $0.2 \mu \mathrm{g}$ template and sterilized nuclease free water to make up the reaction volume. Thermocycler $\left(\operatorname{Biorad}^{\circledR}\right)$ was used to perform the amplification reaction. The cycling conditions included an initial denaturation at $94^{\circ} \mathrm{C}$ for 5 minutes, followed by 30 cycles each of denaturation at $94^{\circ} \mathrm{C}$ for 30 seconds; annealing at $57.7^{\circ} \mathrm{C}$ for 40 seconds and extension at $72{ }^{\circ} \mathrm{C}$ for 1 minute; followed by a final extension at $72{ }^{\circ} \mathrm{C}$ for 5 minutes, and hold at $4{ }^{\circ} \mathrm{C}$. The amplified products were electrophoresed in $1.5 \%$ agarose gel containing ethidium bromide $\left(10 \mu \mathrm{g} \mathrm{mL} \mathrm{mL}^{-1}\right)$ and visualized and imaged using the Molecular Imager ${ }^{\circledR}$ ChemiDoc $^{\mathrm{TM}}$ XRS + imaging system $\left(\operatorname{BioRad}^{\circledR}\right)$.

Amplification of coagulase gene. Isolates were tested for the presence of the coa gene, as per the protocol of GOH et al. (1992), with slight modifications. The primer pair sequence is given in Table 1. The PCR mixture was prepared in a $25 \mu \mathrm{L}$ reaction and amplified using the following protocol: initial denaturation at $95^{\circ} \mathrm{C}$ for $2 \mathrm{~min} ; 30$ cycles of $95{ }^{\circ} \mathrm{C}$ for $30 \mathrm{~s}, 54{ }^{\circ} \mathrm{C}$ for $2 \mathrm{~min}, 72{ }^{\circ} \mathrm{C}$ for $2 \mathrm{~min}$; final extension at $72{ }^{\circ} \mathrm{C}$ for $10 \mathrm{~min}$. The amplified products were electrophoresed in $1.5 \%$ agarose gel containing ethidium bromide $(10 \mu \mathrm{g}$ $\mathrm{mL}^{-1}$ ) and visualized.

Ribosomal spacer PCR (RS-PCR). RS-PCR was carried out using the primers and protocol of JENSEN et al. (1993) with slight modifications. The assay involved $12.5 \mu \mathrm{L}$ of Taq master mix, $1 \mu \mathrm{L}$ each of two primers (primers Gl and L1; 50 pmol; Table 1) and deionized water in a total of $25 \mu \mathrm{L}$ reaction. Reaction mixtures were amplified once at $94{ }^{\circ} \mathrm{C}$ for $5 \mathrm{~min}$ followed by twenty-five amplification cycles at $94{ }^{\circ} \mathrm{C}$ for $1 \mathrm{~min} ; 2$-min ramp to $55^{\circ} \mathrm{C}$ for $7 \mathrm{~min}$; 2 -min ramp to $72{ }^{\circ} \mathrm{C}$ for $2 \mathrm{~min}$ and a final step of $7 \mathrm{~min}$ at $72{ }^{\circ} \mathrm{C}$. The band length of the genotypes was correctly noted by matching the size with an adjacently run molecular DNA marker, and any two strains with the same banding pattern were assigned as similar genotypes, while strains differing in more than one band were assigned as separate genotypes.

Table 1. Primers used in the study

\begin{tabular}{|l|l|l|c|l|}
\hline Organisms & $\begin{array}{l}\text { Primer } \\
\text { designation }\end{array}$ & Oligonucleotide sequence (5'-3') & $\begin{array}{c}\text { Amplicon } \\
\text { size }\end{array}$ & Reference \\
\hline Staphylococcus spp. & $\begin{array}{l}16 \mathrm{~S} \text { rDNA-F } \\
16 \mathrm{~S} \text { rDNA-R }\end{array}$ & $\begin{array}{l}\text { CAG CTC GTG TCG TGA GAT GT } \\
\text { AAT CAT TTG TCC CAC CTT CG }\end{array}$ & 420 & $\begin{array}{l}\text { Strommenger et al., } \\
(2003)\end{array}$ \\
\hline $\begin{array}{l}\text { Staphylococcus } \\
\text { aureus }\end{array}$ & $\begin{array}{l}\text { Nuc-F } \\
\text { Nuc-R }\end{array}$ & $\begin{array}{l}\text { GCGATTGATGGTGATACGGTT } \\
\text { AGCCAAGCCTTGACGAACTAAAGC }\end{array}$ & 280 & $\begin{array}{l}\text { Brakstad et al., } \\
(1992)\end{array}$ \\
\hline Coa gene & $\begin{array}{l}\text { Coa-F } \\
\text { Coa-R }\end{array}$ & $\begin{array}{l}\text { CGAGACCAAGATTCAACAAG } \\
\text { AAAGAAAACCACTCACATCA }\end{array}$ & Variable & Goh et al., (1992) \\
\hline RS-PCR & $\begin{array}{l}\text { G1 } \\
\text { L1 }\end{array}$ & $\begin{array}{l}\text { GAAGTCGTAACAAGG } \\
\text { CAAGGCATCCACCGT }\end{array}$ & Variable & Jensen et al., (1993) \\
\hline Spa gene & $\begin{array}{l}\text { Spa-F } \\
\text { Spa-R }\end{array}$ & $\begin{array}{l}\text { F: AGACGATCCWTCAGTGAGC } \\
\text { R: TAATCACCAAATACAGTTGTACC }\end{array}$ & Variable & $\begin{array}{l}\text { Shopsin et al., } \\
(1999)\end{array}$ \\
\hline
\end{tabular}


PCR for spa (Staphylococcal Protein A) gene amplification. The primers and amplification conditions for spa were used as per protocol the given by SHOPSIN et al. (1999). For PCR amplification of the spa gene a $50 \mu \mathrm{L}$ reaction was used consisting of Q5 High-Fidelity 2X master mix (New England Biolabs), $10 \mathrm{pmol} / \mu \mathrm{L}$ each reverse and forward primer (Table 1), DNA template 0.01 $\mu \mathrm{g}-0.2 \mu \mathrm{g}$ and sterilized nuclease free water to make up the reaction volume, along with negative (sterile deionized water) and positive controls (Standard ATCC 33591).

\section{Results}

54 Staphylococcus aureus isolated from 422 milk samples were correctly identified with the help of duplex PCR (Fig. 1). On the basis of the tube coagulase test, only 44 were coagulase positive; however, the coa gene was detected in 51 isolates.
After visualization, PCR products were sent for sequence analysis (BioServe Pvt. Ltd. Hyderabad, India). The consensus sequences of Staphylococcus aureus were blasted with the BLASTN programme (http:/blast.ncbi.nim.nih.gov/Blast.cgi) to check the identity with sequences available in the NCBI database. The consensus sequences were analysed by DNA gear software, resulting in identification of unique SSR (short sequence repeats) types. The spa (strain) type is defined by the number and sequence of repeats revealed on this analysis. Unique sequences were submitted to an online SpaServer website (spa.ridom.de) for assignment of the strain number.

Genotypes for Staphylococcus aureus on the basis of the coa gene (Fig. 2) and RS-PCR (Fig. 3) were assigned, and corresponding strains belonging to different genotypes were analysed using the frequency distribution given in Table 2 .

Table 2. Molecular epidemiology of Staphylococcus aureus based on coa gene and RS-PCR polymorphism

\begin{tabular}{|c|c|c|c|c|c|c|c|}
\hline \multirow[b]{2}{*}{ S. No. } & \multicolumn{3}{|c|}{ coa gene polymorphism } & \multicolumn{4}{|c|}{ RS-PCR polymorphism } \\
\hline & $\begin{array}{l}\text { Coagulase } \\
\text { Genotype }\end{array}$ & $\begin{array}{l}\text { PCR band } \\
\text { size (bp) }\end{array}$ & $\begin{array}{l}\text { No. of } \\
\text { strains }\end{array}$ & RS genotype & No. of bands & Band range & $\begin{array}{l}\text { No. of } \\
\text { strains }\end{array}$ \\
\hline 1 & CTI & 405 & 1 & GTB & 7 & $390-620$ & 1 \\
\hline 2 & CTII & 670 & 1 & GTB & 7 & $390-620$ & 1 \\
\hline 3 & CTIII & 730 & 35 & GTA & 7 & $430-690$ & 29 \\
\hline 4 & & & & GTB & 7 & $390-620$ & 1 \\
\hline 5 & & & & GTC & 6 & $270-600$ & 1 \\
\hline 6 & & & & GTE & 4 & $430-570$ & 3 \\
\hline 7 & & & & GTF & 5 & $430-630$ & 1 \\
\hline 8 & CTIV & 800 & 4 & GTB & 7 & $390-620$ & 2 \\
\hline 9 & & & & GTC & 6 & $270-600$ & 1 \\
\hline 10 & & & & GTH & 5 & $400-550$ & 1 \\
\hline 11 & CTV & 900 & 7 & GTB & 7 & $390-620$ & 4 \\
\hline 12 & & & & GTH & 5 & $400-550$ & 3 \\
\hline 13 & CTVI & 1400 & 2 & GTB & 7 & $390-620$ & 2 \\
\hline 14 & CTVII & 1000,405 & 1 & GTA & 7 & $430-690$ & 1 \\
\hline 15 & & $\mathrm{~N}$ & & GTA & 7 & $430-690$ & 1 \\
\hline 16 & & $\mathrm{~N}$ & & GTD & 4 & $310-500$ & 1 \\
\hline 17 & & $\mathrm{~N}$ & & GTG & 2 & $50-650$ & 1 \\
\hline
\end{tabular}


T. A. Shafi et al.: Molecular epidemiology of Staphylococcus aureus of bovine mastitis origin

Table 3. Prevalence of Staphylococcus aureus spa strains prevalent in cows in different agro-climatic regions of Punjab

\begin{tabular}{|c|c|c|c|c|c|c|c|c|c|}
\hline \multirow{2}{*}{$\begin{array}{l}\text { Spa } \\
\text { type }\end{array}$} & \multirow[b]{2}{*}{ Spa repeats } & \multirow{2}{*}{$\begin{array}{l}\text { No. of } \\
\text { Strains } \\
\text { Cows }\end{array}$} & \multicolumn{5}{|c|}{ Strains in agro-climatic regions } & \multicolumn{2}{|c|}{ First Reported } \\
\hline & & & $\mathrm{CPZ}$ & UPZ & SMUZ & WZ & WPZ & India & Abroad \\
\hline t18462 & $\begin{array}{l}07-16-12-23-02-02- \\
34-34-34-34\end{array}$ & 1 & 1 & & & & & This study & ND \\
\hline t005 & $\begin{array}{l}26-23-13-23-31-05- \\
17-25-17-25-16-28\end{array}$ & 1 & 1 & & & & & 2007 & $\begin{array}{l}\text { Germany, } \\
2001\end{array}$ \\
\hline t008 & $\begin{array}{l}11-19-12-21-17-34- \\
24-34-22-25\end{array}$ & 1 & & & & 1 & & $\begin{array}{l}2007 \\
\text { Mitra et al., } 2013\end{array}$ & $\begin{array}{l}\text { Germany, } \\
2001\end{array}$ \\
\hline t091 & $\begin{array}{l}07-23-21-17-34-12- \\
23-02-12-23\end{array}$ & 3 & 2 & & & & 1 & Gulazar, 2017 & $\begin{array}{l}\text { Germany, } \\
2014\end{array}$ \\
\hline t13078 & $\begin{array}{l}26-23-13-23-31-17- \\
25-17-25-16-28\end{array}$ & 1 & 1 & & & & & Gulazar, 2017 & $\begin{array}{l}\text { Germany, } \\
2013\end{array}$ \\
\hline $\mathrm{t} 131$ & $07-23-12-34-33-34$ & 1 & 1 & & & & & This study" & $\begin{array}{l}\text { Belgium, } \\
2004\end{array}$ \\
\hline $\mathrm{t} 15515$ & $\begin{array}{l}07-16-12-23-02-02- \\
34-34-34\end{array}$ & 4 & 1 & 3 & & & & 2014 & - \\
\hline t15889 & $\begin{array}{l}07-16-12-23-02-12- \\
23-02-34-34\end{array}$ & 1 & 1 & & & & & This study & $\begin{array}{l}\text { Denmark, } \\
2016\end{array}$ \\
\hline $\mathrm{t} 159$ & $\begin{array}{l}14-44-13-12-17-17- \\
23-18-17\end{array}$ & 1 & & 1 & & & & This study" & $\begin{array}{l}\text { Germany, } \\
2004\end{array}$ \\
\hline $\mathrm{t} 1598$ & $\begin{array}{l}07-12-21-13-13-34- \\
34-33-34\end{array}$ & 1 & & 1 & & & & This study & UK, 2006 \\
\hline t1659 & $07-16-12-23-02-02-34$ & 1 & & & & 1 & & This study ${ }^{\#}$ & $\begin{array}{l}\text { Germany, } \\
2006\end{array}$ \\
\hline t1839 & $\begin{array}{l}26-23-13-21-17-34- \\
34-34-33-34\end{array}$ & 1 & & 1 & & & & 2006 & $\begin{array}{l}\text { Germany, } \\
2008\end{array}$ \\
\hline t3841 & $\begin{array}{l}26-22-17-20-17-12- \\
17-16-16\end{array}$ & 1 & & 1 & & & & 2008 & $\begin{array}{c}\text { Netherlands, } \\
2014\end{array}$ \\
\hline $\mathrm{t} 386$ & $07-23-13$ & 1 & 1 & & & & & This study ${ }^{\#}$ & Sweden, 2004 \\
\hline $\mathrm{t} 4363$ & $\begin{array}{l}26-23-13-21-17-34- \\
34-24-33-34\end{array}$ & 1 & & & & 1 & & This study & China, 2008 \\
\hline $\mathrm{t} 442$ & $\begin{array}{l}35-17-34-17-20-17- \\
12-17-16\end{array}$ & 1 & 1 & & & & & 2016 & Norway, 2008 \\
\hline $\mathrm{t} 4812$ & $07-16-12-23-02-34$ & 2 & 2 & & & & & This study\# & Poland, 2009 \\
\hline t5919 & $\begin{array}{l}07-21-17-13-13-13- \\
34-33-34\end{array}$ & 1 & & 1 & & & & This study ${ }^{\#}$ & UAE, 2009 \\
\hline t605 & $\begin{array}{l}07-23-38-101-23-02- \\
72-23\end{array}$ & 1 & 1 & & & & & This study & Sweden, 2005 \\
\hline $\mathrm{t} 7286$ & $07-16-12-23-02-34-34$ & 4 & 2 & 2 & & & & 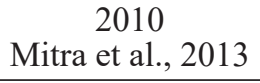 & - \\
\hline $\mathrm{t} 7867$ & $\begin{array}{l}07-16-12-23-02-02- \\
34-34\end{array}$ & 11 & 3 & 2 & 1 & 4 & 1 & $\begin{array}{c}2011 \\
\text { Mitra et al., } 2013\end{array}$ & - \\
\hline
\end{tabular}

UPZ: Upper plain Zone, CPZ: Central Pain Zone, SMUZ: Sub-Mountainous Undulating Zone, WZ: Western Zone, WPZ: Western plain Zone; ND: not reported in any other country (new spa strain); ${ }^{\#}$ Strains reported first time from India in this study $(\mathrm{n}=10)$ 


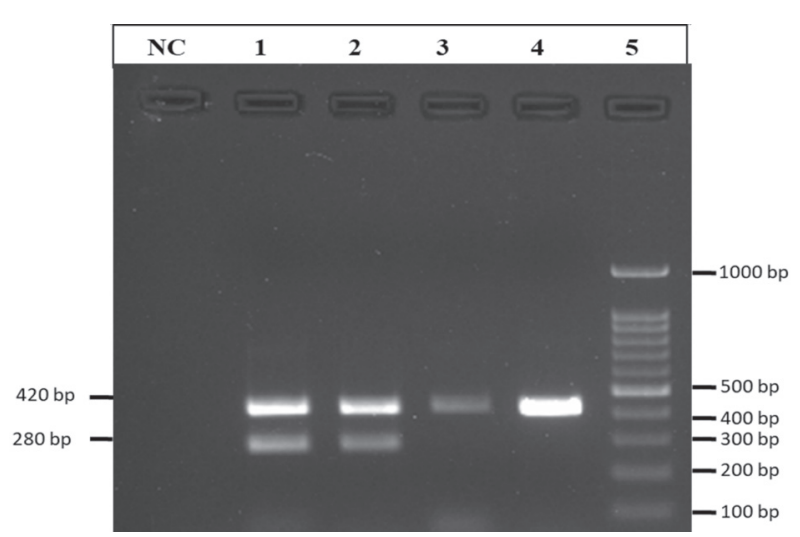

Fig. 1. Electrophoresis image of mPCR for $16 \operatorname{SrDNA}$ (420bp) and nuc (280np) genes. Lanes indicate

NC: negative control, 1: Staphylococcus aureus 2: Staphylococcus aureus positive control (ATCC 33591) 3: Staphylococcus spp. 4: S. epidermidis positive control (MTCC 3382). M indicate ExcelBand 100 bp DNA ladder (DM2300, SMOBio).

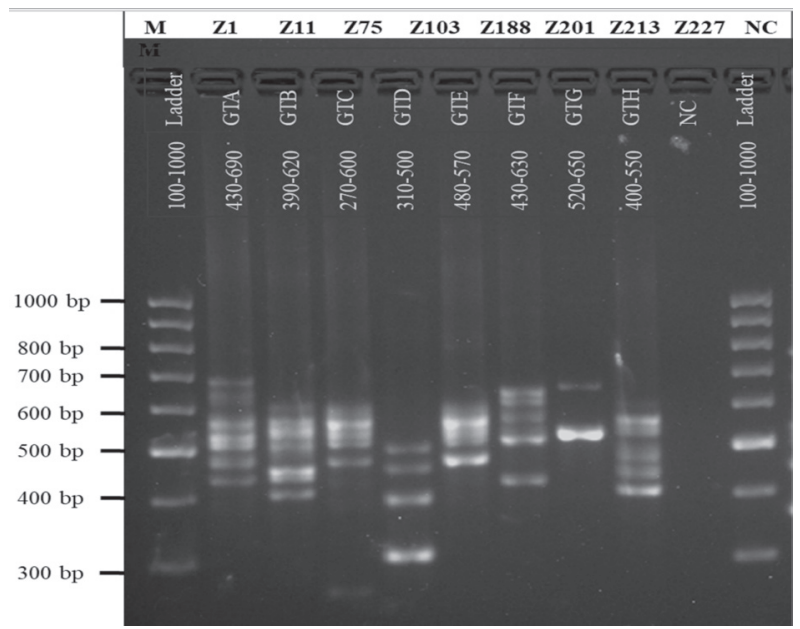

Fig. 3. Electrophoresis image of RS-PCR

polymorphism of Staphylococcus aureus. RS genotypes of $S$. aureuas (lanes 2-9). NC indicate negative control (nuclease free water). $\mathrm{M}$ indicate SMOBio ExcelBand 100 bp DNA ladder (DM2100)

The prevalence of spa strains of Staphylococcus aureus (Fig. 4) in the different agro-climatic regions of Punjab is given in Table 3. Forty out of 54 Staphylococcus aureus were correctly typed by spa typing and assigned to 21 known spa types, and one novel spa type, t18462, was assigned on

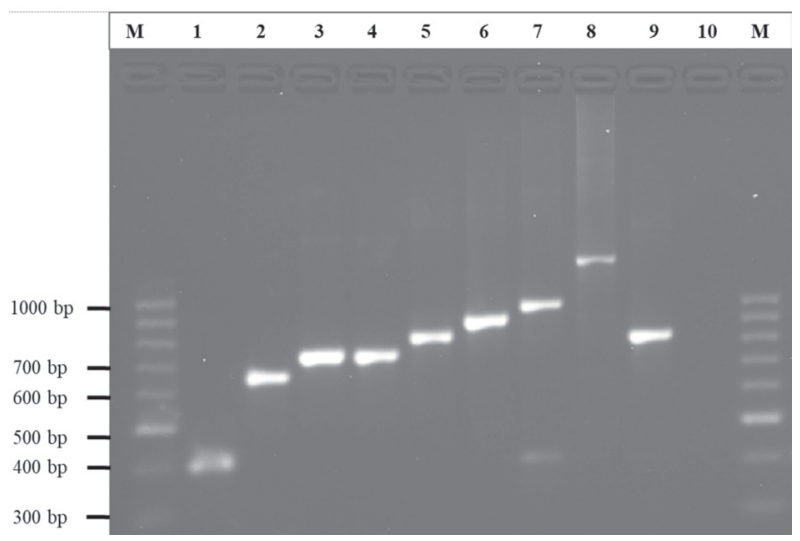

Fig. 2. Electrophoresis image of coa gene polymorphism of Staphylococcus aureus. Isolates from cows (lane 1-8). M indicate GeneRuler 100 bp DNA ladder (SM0243, Thermo Scientific) and lanes 9 and 10 indicate Staphylococcus aureus positive control (ATCC 33591) and S. epidermidis negative control (MTCC 3382).

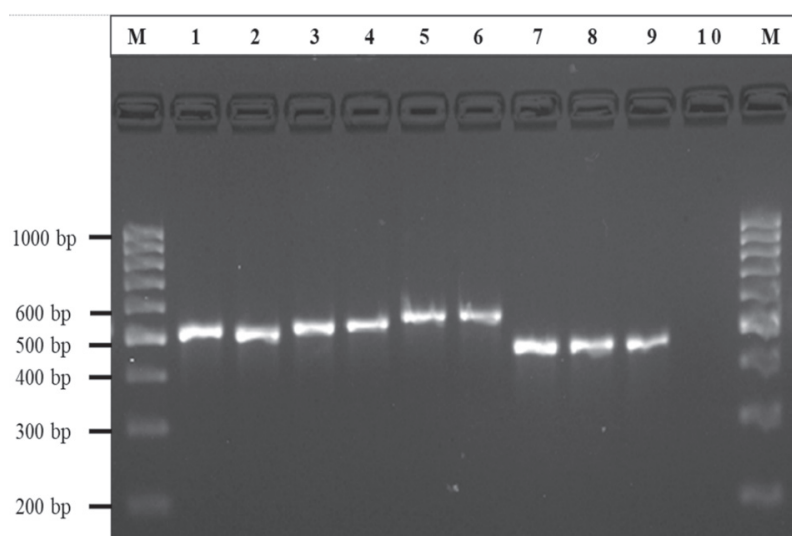

Fig. 4. Electrophoresis image of Spa gene.

Lanes 1-9 indicate amplified products of spa gene of Staphylococcus aureus of varied sizes ranging from 450 to 580 base pairs and lane 10 indicate $S$. epidermidis negative control (MTCC 3382). M indicate SMOBio

ExcelBand 100 bp DNA ladder (DM2100).

$17^{\text {th }}$ December 2018 (online SpaServer website available at: http://spa.ridom.de/frequencies.shtml). t18462 is a mecA negative strain, isolated from a SCM cow. Spa strain 7867 was observed to be most diverse in the present study, and was prevalent in cows in all five agro-climatic regions of the Punjab. 


\section{Discussion}

The molecular epidemiology of Staphylococcus aureus was studied using coa gene polymorphism, 16S-23S ribosomal spacer polymorphism and Spa typing. Coagulase production is an important phenotypic feature of Staphylococcus aureus, and coagulase gene polymorphism has been used to understand epidemiology, due to its high reproducibility and good discriminatory power (GOH et al., 1992; SU et al., 1999; KARAHAN and CETINKAYA, 2007). The predominance of strains in fewer coagulase clusters had been reported by other workers as well (HIMABINDU et al., 2009; MOMTAZ et al., 2011). Coa gene amplification in all but one strain produced a single band, one strain produced a double band $(1000,405)$ and, as has also been reported earlier (ASLANTAS et al., 2007), were attributed to different allelic forms of the coa gene (GOH et al., 1992). FOURNIER et al. (2008) reported high diversity within 16S-23S rRNA spacer regions, reporting 17 RS genotypes, out of which 2 genotypes were predominant, comprising $80.2 \%$ of the isolates that were also positive for virulence genes. GRABER (2016), proved the superiority of RS-PCR over spa typing and MLST, with resolution comparable to spa typing or better than MLST or PFGE. The predominance of strains into fewer genotypes has been attributed to resistance to phagocytosis by neutrophils (SU et al., 1999), or coevolution of the pathogens and their host, herd management, and differences in the reservoirs and environment of each geographical area (ASLANTAS et al., 2007). The predominance of one of the genotypes/strains confirms high contagiousness, and the dissemination of predominant strains of Staphylococcus aureus within dairy herds. Staphylococcus aureus showed high diversity by spa typing, assigning 40 isolates into 22 spa types, out of which 10 spa types were reported for the first time in India, and one novel spa type t18462 was also reported. A high diversity in spa types of Staphylococcus aureus isolated from healthcare and community-acquired infections has been reported in India (GULZAR, 2017; SINGH et al., 2018) and abroad (HARASTANI et al., 2014; MOHAMMADI et al., 2014; KHADEMI et al., 2016), and has been attributed to deletions or duplications, or more seldomly, to point mutations (SHOPSIN et al., 1999). In India, spa types t359, t6877, t008 have been reported as predominant bovine mastitis strains, and t267 as an endemic clone responsible for subclinical mastitis (MITRA et al., 2013). SINGH et al. (2018) reported t021 (14.1\%), t127 (9.6\%), t657 (9.2\%), t3841 $(8.8 \%), \mathrm{t} 1149(6.0 \%)$ and $\mathrm{t} 309(4.0 \%)$ as the most prevalent spa types of Staphylococcus aureus obtained from various human clinical samples from Haryana, India, a neighbouring state, sharing a geographical boundary with Punjab. Spa types, t091 and t13078 observed in the present study were reported by GULZAR (2017) from bovine milk and a telephone surface (community associated). However, observation of t13078 in milk has only been reported in the present study. Staphylococcus aureus showed good diversity that may be helpful in understanding the epidemiology and clonal relationships in investigating disease outbreaks. The varied types of spa types observed in the present study, and the observation that they were also isolated from community sources, indicate the possible transfer of these strains from community associated sources to animals or vice versa, and indicates their zoonotic potential.

In conclusion, the study revealed high diversity within Staphylococcus aureus strains, consisting of 7 coagulase genotypes, 8 RS genotypes and 21 known spa types, and one novel spa type (t18462). Spa typing was found to be the most discriminatory technique, followed by RS PCR and coa polymorphism, in this study. The predominance of one of the genotypes/strains in this study confirmed the high contagiousness and dissemination of predominant strains of Staphylococcus aureus within dairy herds.

\section{Conflict of Interest}

The authors declare that they have no conflict of interest.

\section{Acknowledgements}

The authors sincerely acknowledge the Director of Research, Guru Angad Dev Veterinary and Animal Sciences University, and the Dean of the College of Veterinary Science, for providing the necessary facilities to carry out the research. The help and cooperation of the farmers is also duly acknowledged. 


\section{References}

ASLANTAS, O., C. DEMIR, H. TÜRÜTOGLU, Z. CANTEKIN, Y. ERGÜN, G. DOGRUER (2007): Coagulase Gene Polymorphism of Staphylococcus aureus isolated from Subclinical Bovine Mastitis. Turk. J. Vet. Anim. Sci. 31, 253-257.

BARRY, T., G. COLLERAN, M. GLENNON, L. K. DUNICAN, F. GANNON (1991): The 16S/23S ribosomal spacer region as a target for DNA probes to identify eubacteria. PCR Methods Appl. 1, 51-56.

DOI: $10.1101 /$ gr.1.1.51

BRAKSTAD, O. G., K. AASBAKK, J. A. MAELAND (1992): Detection of Staphylococcus aureus by polymerase chain reaction amplification of the nuc gene. J. Clin. Microbiol. 30, 1654-1660.

DOI: $10.1128 / \mathrm{jcm} .30 .7 .1654-1660.1992$

BUSCH, U., H. NITSCHKO (1999): Methods for the differentiation of microorganisms. J. Chromatogr. B. Biomed. Sci. Appl. 722(1-2), 263-278.

D'AMICO, D., C. DONNELLY (2011): Characterization of Staphylococcus aureus strains isolated from raw milk utilized in small-scale artisan cheese production. J. Food Prot. 74, 1353-1358.

DOI: 10.4315/0362-028x.jfp-10-533

EBERHART, R. J., D. E. HARMON, R. P. JASPER, S. C. NATZKE (1987): Current concepts of bovine mastitis. 3rd National Mastitis Council. Inc., Arlington, VA, pp. 258264.

ENRIGHT, M. C., N. P. DAY, C. E., DAVIES, S. J. PEACOCK, B. G. SPRATT (2000): Multilocus sequence typing for characterization of methicillin-resistant and methicillinsusceptible clones of Staphylococcus aureus. J. Clin. Microbiol. 38, 1008-1015.

DOI: $10.1128 / \mathrm{jcm} .38 .3 .1008-1015.2000$

FOURNIER, C., P. KUHNERT, J. FREY, R. MISEREZ KIRCHHOF, T. KAUFMAN, A. STEINER, H. U. GRABER (2008): Bovine Staphylococcus aureus: association of virulence genes, genotypes and clinical outcome. Res. Vet. Sci. 85, 439-448.

DOI: $10.1016 /$ j.rvsc.2008.01.010

FRENAY, H. M., A. E. BUNSCHOTEN, L. M. SCHOULS, V. W. J. LEEUWEN, C. M. VANDENBROUCKE-GRAULS, J. VERHOEF, F. R. MOOI (1996): Molecular typing of methicillin-resistant Staphylococcus aureus on the basis of protein A gene polymorphism. Eur. J. Clin. Microbiol. Infect. Dis. 15, 60-64.

DOI: $10.1007 / \mathrm{bf0} 1586186$

GOH, S. H., S. K. BYRNE, J. L. ZHANG, A.W. CHOW (1992): Molecular typing of Staphylococcus aureus on the basis of coagulase gene polymorphisms. J. Clin. Microbiol. 30, 1642-1645.

DOI: $10.1128 /$ jcm.30.7.1642-1645.1992
GRABER, H. U. (2016): Genotyping of Staphylococcus aureus by Ribosomal Spacer PCR (RS-PCR). J. Vis. Exp. 117, e54623,

DOI: $10.3791 / 54623$

GULZAR, M. (2017): Characterization of antibiotic resistant Staphylococcus aureus molecular clusters and types associated with food of animal origin. MVSc Thesis, Guru Angad Dev Veterinary and Animal Sciences University, Veterinary Public Health and Epidemiology, GADVASU, Ludhiana, India.

DOI: $10.23910 /$ ijbsm/2019.10.1.1934

GUPTA, D. K., T. A. SHAFI, B. K. BANSAL, S. SHARMA (2015): Microbiological profile of organisms from clinical and subclinical mastitis in dairy animals. Progressive Research: an International Journal 10 (Special-1), 631-632.

HAFTU, R., H. TADDELE, G. GUGSA, S. KALAYOU (2012): Prevalence, bacterial causes, and antimicrobial susceptibility profile of mastitis isolates from cows in large-scale dairy farms of Northern Ethiopia. Trop. Anim. Health Prod. 44, 1765-1771.

DOI: $10.1007 / \mathrm{s} 11250-012-0135-\mathrm{z}$

HARASTANI, H. H., G. F. ARAJ, S. T. TOKAJIAN (2014): Molecular characteristics of Staphylococcus aureus isolated from a major hospital in Lebanon. Int. J. Infect. Dis. $19,33-38$.

DOI: $10.1016 /$ j.ijid.2013.10.007

HIMABINDU, M., D. M. SUGAPRIYA, D. K. BISHI, R. S. VERMA (2009): Molecular Analysis of Coagulase Gene Polymorphism in Clinical Isolates of Methicilin Resistant Staphylococcus aureus by Restriction Fragment Length Polymorphism Based Genotypin. Am. J. Infect. Dis. 5, 170-176.

DOI: $10.3844 /$ ajidsp.2009.170.176

HOGAN, J., N. GONZALESM R. J. HARMON, S. C. NICKERSON, S. P. OLIVER, J. W. PANKEY, B. SODERQUIST (1999): Laboratory Handbook on Bovine Mastitis. Revised edition. National Mastitis Council Inc., Madison, WI.

ISHINO, K., N. TSUCHIZAKI, J. ISHIKAWA, K. HOTTA (2007): Usefulness of PCR-restriction fragment length polymorphism typing of the coagulase gene to discriminate arbekacin-resistant methicillin-resistant Staphylococcus aureus strains. J. Clin. Microbiol. 45, 607-609.

DOI: 10.1128/jcm.02099-06

JENSEN, M. A., J. A. WEBSTER, N. STRAUS (1993): Rapid identification of bacteria on the basis of polymerase chain reaction amplified ribosomal DNA spacer polymorphisms. Appl. Environ. Microbiol. 59, 945-952.

DOI: $10.1128 /$ aem.59.4.945-952.1993

KARAHAN, M., B. CETINKAYA (2007): Coagulase gene polymorphisms detected by PCR in Staphylococcus aureus isolated from subclinical bovine mastitis in Turkey. Vet. J. 174, 428-431.

DOI: 10.1016/j.tvj1.2006.05.016 
KARIMURIBO, E. D., L. J. KUSILUKA, R. H. MDEGELA, A. M. KAPAGA, C. SINDATO, D. M. KAMBARAGE (2005): Studies on mastitis, milk quality and health risks associated with consumption of milk from pastoral herds in Dodoma and Morogoro regions, Tanzania. J. Vet. Sci. 6, 213-221.

DOI: 10.4142 /jvs.2005.6.3.213

KHADEMI, F., F. GHANBARI, A. MELLMANN, M. J. NAJAFZADEH, A. KHALEDI (2016): Phylogenetic relationships among Staphylococcus aureus isolated from clinical samples in Mashhad, Iran. J. Infect. Public Health. 9, 639-644

DOI: $10.1016 /$ j.jiph.2016.01.003

KOREEN, L., S. V. RAMASWAMY, E. A. GRAVISS, S. NAIDICH, J. M. MUSSER, B. N. KREISWIRTH (2004): Spa typing method for discriminating among Staphylococcus aureus isolates: implications for use of a single marker to detect genetic micro- and macro-variation. J. Clin. Microbiol. 42, 792-799.

DOI: $10.1128 /$ jcm.42.2.792-799.2004

LANGE, C., M. CARDOSO, D. SENCZEK, S. SCHWARZ (1999): Molecular subtyping of Staphylococcus aureus isolates from cases of bovine mastitis in Brazil. Vet. Microbiol. 67, 127-141.

DOI: $10.1016 / \mathrm{s} 0378-1135(99) 00031-0$

MALACHOWA, N., F. R. DELEO (2010): Mobile genetic elements of Staphylococcus aureus. Cell Mol. Life Sci. 67, 3057-3071.

DOI: $10.1007 / \mathrm{s} 00018-010-0389-4$

MELLES, D. C., W. B. VAN LEEUWEN, S. V. SNIJDERS D. HORST-KREFT, J. K. PEETERS, H. A. VERBRUGH, A. VAN BELKUM (2007): Comparison of multilocus sequence typing (MLST), pulsed-field gel electrophoresis (PFGE), and amplified fragment length polymorphism (AFLP) for genetic typing of Staphylococcus aureus. J. Microbiol. Methods. 69, 371-375.

DOI: 10.1016/j.mimet.2007.01.013

MITRA, S. D., D. VELU, M. BHUVANA, N. KRITHIGA, A. BANERJEE, R. SHOME, H. RAHMAN, S. K. GHOSH, B. R. SHOME (2013): Staphylococcus aureus spa type t267, clonal ancestor of bovine subclinical mastitis in India. J. Appl. Microbiol. 114, 1604-1615.

DOI: $10.1111 /$ jam.12186

MOHAMMADI, S., Z. SEKAWI, A. MONJEZI, M. H. MALEKI, S. SOROUSH, N. SADEGHIFARD, I. PAKZAD F. AZIZI-JALILIAN, M. EMANEINI, K. ASADOLLAHI, F. POURAHMAD, R. ZARRILLI, M. TAHERIKALANI (2014): Emergence of SCCmec type III with variable antimicrobial resistance profiles and spa types among methicillin-resistant Staphylococcus aureus isolated from healthcare- and community-acquired infections in the west of Iran. Int. J. Infect. Dis. 25,152-158.

DOI: 10.1016/j.ijid.2014.02.018
MOMTAZ, H., E. TAJBAKHSH, E. RAHIMI, M. MOMENI (2011): Coagulase gene polymorphism of Staphylococcus aureus isolated from clinical and sub-clinical bovine mastitis in Isfahan and Chaharmahal va Bakhtiari provinces of Iran. Comp. Clin. Path. 20, 519-522.

DOI: $10.1007 / \mathrm{s} 00580-010-1029-y$

SPASERVER WEBSITE - (http://spa.ridom.de/frequencies.shtml) accessed on $17^{\text {th }}$ December 2018.

SHOPSIN, B., M. GOMEZ, S. O. MONTGOMERY, D. H. SMITH, M. WADDINGTON, D. E. DODGE, D. A. BOST, M. RIEHMAN, S. NAIDICH, B. N. KREISWIRTH (1999): Evaluation of protein A gene polymorphic region DNA sequencing for typing of Staphylococcus aureus strains. J. Clin. Microbiol. 37, 3556-3563.

DOI: $10.1128 /$ jcm.37.11.3556-3563.1999

SINGH, G., S. BROORV, P. AGARWAL (2018): Molecular characterisation of Staphylococcus aureus using spa typing as a diagnostic tool in Haryana, India. Indian J. Med. Microbiol. 36, 26-31.

DOI: 10.4103/ijmm.ijmm_17_330

STROMMENGER, B., C. KETTLITZ, G. WERNER, W. WITTE (2003): Multiplex PCR assay for simultaneous detection of nine clinically relevant antibiotic resistance genes in Staphylococcus aureus. J. Clin. Microbiol. 41, 4089-4094.

DOI: $10.1128 / \mathrm{jcm} .41 .9 .4089-4094.2003$

SU, C., C. HERBELIN, N. FRIEZE, O. SKARDOVA, L. M. SORDILLO (1999): Coagulase gene polymorphism of Staphylococcus aureus isolates from dairy cattle in different geographical areas. Epidemiol. Infect. 122, 329-336. DOI: $10.1017 / \mathrm{s} 0950268899002228$

ZADOKS, R., W. VAN LEEUWEN, H. BARKEMA, O. SAMPIMON, H. VERBRUGH, Y. H. SCHUKKEN, A. VAN BELKUM (2000): Application of pulsed-field gel electrophoresis and binary typing as tools in veterinary clinical microbiology and molecular epidemiologic analysis of bovine and human Staphylococcus aureus isolates. J. Clin. Microbiol. 38, 1931-1939.

DOI: $10.1128 / \mathrm{jcm} .38 .5 .1931-1939.2000$ 
SHAFI, T. A., B. K. BANSAL, S. SHARMA, D. K. GUPTA, R. SINGH: Molekularna epidemiologija bakterije Staphylococcus aureus izolirane iz mlijeka krava s mastitisom. Vet. arhiv 91, 1-10, 2021.

\section{SAŽETAK}

Istraživanje je provedeno kako bi se razumjela molekularna epidemiologija bakterije Staphylococcus aureus. Ukupno 54 izolata iz 422 uzorka mlijeka dobivena su od 108 krava sa supkliničkim mastitisom (CMT pozitivni $\geq$ $1+\mathrm{u}$ barem jednoj četvrtini vimena). Molekularna epidemiologija S. aureus analizirana je upotrebom polimorfizma koagulaza-gena (coa), polimorfizma 16S-23S ribosomske regije razdvajanja (RS-PCR) i tipiziranjem stafilokoknog proteina A (Spas). Bakterija S. aureus proizvela je 7 genotipova koagulaza i 8 RS genotipova. Koagulaza genotip GTIII (730 bp) bio je najčešći (35 sojeva), zatim GTV (900 bp, 7 sojeva) i GTIV ( 800 bp, 4 soja), dok je kod RS genotipova najveći broj sojeva sadržavao GTA (31 soj), zatim GTB (11 sojeva), GTH (4 soja) i GTE (3 soja). Koagulaza genotip CTIII (730 bp) pokazao je najveću raznolikost jer su izolati unutar njega proizveli 5 RS genotipova, a većina njih pripadala je RS genotipu GTA (29 od 31 soja). Četrdeset od 54 uzorka bakterije S. aureus izolirana u ovom istraživanju bilo je ispravno tipizirano spas tipiziranjem, i pripisano 21 poznatom spas tipu te jednom novom spas tipu, t18462. Istraživanje je pokazalo veliku raznolikost sojeva bakterije $\mathrm{S}$. aureus s obzirom na postojanje 7 koagulaza genotipova, 8 RS genotipova i 22 spas tipa.

Ključne riječi: polimorfizam gena coa; polimorfizam ribosomske regije razdvajanja; Staphylococcus aureus; spas tipiziranje 